Фролов В. С., к.військ.н., с.н.с.;

Саганюк Ф. В., к.юр.н., доцент;

Лобко М. М., к.військ.н., доцент

Центр воєнно-стратегічних досліджень Національного університету оборони України імені Івана Черняхівського, Київ

\title{
Деякі підходи щодо стратегії протистояння та протидії aгресору
}

\begin{abstract}
Резюме. Проаналізовані наукові та організаційно-правові підходи щодо формування в секторі безпеки і оборони України стратегії мирного протистояння та протидії агресору.

Ключові слова: агресор, активна оборона, сектор безпеки і оборони України, сили оборони.
\end{abstract}

Постановка проблеми. Зараз дедалі стає очевидним, що неоголошений напад збройних сил Росії за рішенням нинішніх іiі правителів на територію України i застосування на східних рубежах та в Криму воєнної сили проти суверенітету, територіальної цілісності та незалежності України або будь-яким іншим способом, несумісні зі Статутом $\mathrm{OOH}$, міжнародним правом та визначаються як агресія (від лат. aggression - нanad) [1].

Серед інших способів до даного ганебного нелюдського акту згідно з нормами міжнародного права належить віднести i напад збройних сил Росії на військові сухопутні, морські, повітряні сили та військові кораблі України, анексію Криму, окупацію частини території східних областей України тощо [1].

Треба зрозуміти, що тут йдеться не про громадянську війну, якою агресор відчайдушно намагається наректи у Гаазькому суді свою відверту збройну агресію, $з$ використанням самого новітнього озброєння та смертоносної військової техніки. Це очевидно усій світовій спільноті [2].

Згідно Воєнній доктрині України - це збройне зіткнення між двома державами в межах території України за активного його ведення та безперервної всебічної підтримки правителями Російської Федерації спеціально фахово навченим іiі військовим особовим складом 3 використанням більш ніж 40 видів різноманітної сучасної воєнної техніки і озброєння.

Російська Федерація уже відправила на Донбас близько 1 тисячі різних артилерійських систем, понад 400 танків і 200 ракетних систем залпового вогню. Зараз там скупчено близько 4200 осіб РФ і 40 тисяч бойовиків, та ще приблизно 23 тисячі військовослужбовців в окупованому Криму [2]. Отже, - це війна, в якій уже вбито понад 10 тисяч українців - цивільних і військових. Вона триває i сьогодні [3]. Загалом Моніторинговою місією ООН з прав людини в Україні задокументовано 33146 жертв конфлікту серед мирного населення, військових i збройних груп: 9900 загинули i 23246 поранені [4].

Громадянська війна - це зовсім інший формат боротьби. Така, зазвичай, ведеться між громадянами одного суспільства чи країни за владу, рідше всього, між двома ii утвореннями на уламках раніше єдиної держави, а не російським агресором.

Які існують пояснення причин иієї братовбивчої "руської акцій” $і$ як протидіяти iü?

Пошук оптимальної відповіді на ці питання - основний задум авторів цієї статті.

Аналіз останніх досліджень i публікацій. Російська агресія, як наголошено Президентом України, все ще триває, i військова загроза зі Сходу очевидна на довгу історичну перспективу - це визначальні чинники нашої політики безпеки і військового планування [5].

Зараз більшість дослідників ведуть активний пошук нових підходів для більш ефективної протидії російському агресору. Зокрема, академік В. П. Горбулін у [6] окреслив п'ять сценаріїв, за якими може бути подальший розвиток зазначених подій, у тому числі і 3 питань Криму.

Перший заступник Міністра оборони України доктор військових наук, професор I. С. Руснак у своій статті [7] аналізує досвід оборонного будівництва в умовах гібридної війни, уточнюе пріоритети подальшого укріплення оборони держави, наводить основні перспективні напрями щодо протидії зовнішній 
агресії, викладає свої авторські погляди на концептуальні та програмні засади подальшої розбудови національної оборони 3 урахуванням міжнародного аспекту безпеки, підкреслює важливість подальшого розвитку сектора безпеки і оборони України як цілісної системи тощо. У [8] він обгрунтовує і деякі інші шляхи щодо необхідності своєчасного та адекватного реагування на сучасні виклики i загрози 3 урахуванням суттєвих змін у геополітичному просторі й українському суспільстві та допущених прорахунків.

Однак, у цій обстановці, як стверджує, британський генерал заступник Верховного головнокомандувача ОЗС НАТО Едріан Бредшоу, щоб протистояти Путіну потрібна “велика стратегія" [9]. Над цим варто працювати зараз.

Мета статті. Проаналізувати зазначену проблему, окреслити можливі шляхи та напрями формування нової стратегії протидії російській агресії для покращення спроможності Збройних Сил та інших складових сил безпеки і оборони, підвищення їх готовності до відбиття збройної агресії.

Виклад основного матеріалу. Російська агресія, яка розпочата в лютому 2014 р. у АР Крим і продовжена на сході України, як наголосив у своєму зверненні Президент України [10], є виявом зухвалого ставлення Росії до загальноприйнятих норм моралі, міжнародного права та відвертим ігноруванням наданих нею гарантій безпеки нашій державі. Офіційно заперечуючи свою причетність до збройного конфлікту в окремих районах Донецької i Луганської областей, насправді РФ $є$ головним його учасником. При цьому керована Росією динаміка агресії набула тенденції до розширення форм і способів iï здійснення та збільшення чисельності залучених до неї сил. Розпочавши із засилання на територію України терористичних груп i найманців, інспірування дій сепаратистських сил, Росія перейшла до застосування проти України регулярних військових частин 3 активним використанням криміналітету.

В умовах такого комплексного характеру агресії особливого значення набуває завершення формування сектора безпеки i оборони України та його подальший розвиток. Забезпечення у межах цього функціонального об'єднання координованості дій усіх його складових, ефективного нарощування їх спроможностей і ресурсів є однією з головних умов успішного протистояння агресивній політиці Росії. Усвідомлення важливості зазначеного має реалізовуватися у практичній площині [10].

Які причини такої агресивної поведінки “братерської” держави?

Пояснення перше. Деякі мілітаристи стверджують, що збройне протистояння ніби грунтується на волі переважної більшості населення, як це зараз пояснюють й російські правителі. Однак, історія знає небагато воєн, які стали результатом волевиявлення народів. Частіше всього народ насильно втягувався у війну своїми правителями. Не є винятком і так зване "всенародне волевиявлення руського народу” проти України і не тільки.

Сучасні дослідження доводять, що ставлення населення до війни переважно нейтральне, а війни відбуваються лише тоді, коли до влади приходять лідери з психологічно ненормальним станом та відношенням до людських жертв. Серед таких називають Наполеона, Гітлера, Македонського і деяких нинішніх російських правителів. Вони очолили свої держави саме в часи криз, коли населення шукало ватажка (кумира) 3 твердою волею i рукою, який, як їм здавалося, здатний вирішити їхні житейські проблеми. Але це суперечить навіть християнській заповіді.

Вкрай небезпечною виявляється нині й “стратегія повернення агресором руського міру”. Про це йдеться навіть у інтерв'ю Financial Times британського генерала заступника Верховного головнокомандувача О3С НАТО Едріана Бредшоу. Він небезпідставно стверджує, що Росія залишиться загрозою до тих пір, поки іi президент Путін буде при владі і що наслідки можуть бути катастрофічними, якщо Захід втратить узгодженість у відповіді “противнику, в руках якого всі важелі влади” [9].

Пояснення друге. Агресивні наміри та дії російських правителів щодо розширення ніби своїх руських національних інтересів, боротьбу за лідерство у геополітичному просторі та посилення впливу на міжнародній арені можна умовно виділити на чотири основні етапи.

Eman перший стосується вирішення Російською Федерацією внутріполітичних проблем після зупинення на ¥ї території демократичних процесів, що розпочалися 3 розпадом СРСР та формуванням нової ідеологічної платформи, створенням зручних владі політичних партій з метою забезпечення ii диктатури. Протистояння руській диктатурі привело до війни на Кавказі, яка забрала життя тисяч безвинних людей.

Eman другий - відновлення політичної та економічної незалежності пострадянських 
республік, що викликало шалену протидію Росії ї демократичним перетворенням та недопущення самостійного їх виходу на геополітичний та геоекономічний простір. Для цього Росія нарощує неабияку воєнну силу та розгорнула пряму воєнну агресію і захоплення окремих територій пострадянських республік, як це відбулося у Придністров’”, Грузії та Україні.

Eman mретій - створення Росією ряду міжнародних об'єднань 3 метою економічного протистояння Заходу та підвищення своєї ролі на геоекономічному просторі: ШОС (Китай, Росія, Киргизія, Казахстан, Таджикистан та Узбекистан); БРІКС (Бразилія, Росія, Індія, Китай, Південна Африка), а для об'єднання сировинних регіонів - Африка, Південна Америка та Азія 3 потужним виробничим потенціалом Китаю, Росії, Індіі.

Eman четвертий - безпрецедентне нарощування Росією воєнно-промислового комплексу та воєнно-економічного потенціалу 3 метою залякування світової спільноти в ході геополітичного суперництва та для створення військової переваги над збройними силами сусідніх держав.

Своєю стратегічною метою Росія визначила повернення колишніх територій Російської імперії будь-якими способами i методами аж до прямої відкритої агресії проти пострадянських республік. Для цього вона 3 2014 року доктринально визначила правомірним застосування своїх збройних сил за межами Російської Федерації та й використання ядерної зброї ніби у відповідь на застосування проти неї або іiі союзників навіть звичайної зброї.

Аналіз причин військових конфліктів, розв'язаних Російською Федерацією проти Грузії та України підтверджує, що ця доктрина лежить в основі сучасної воєнної політики Росії, яка створила i продовжує створювати нові виклики та загрози воєнного характеру для усього цивілізованого світу.

Яка можлива стратегія протидї aгpecopy?

Як нам бачиться, сучасну стратегію боротьби України 3 російським агресором доцільно зосередити на чотирьох напрямах.

Напрям перший - мирний илях відстоювання економічних, енергетичних, ринкових, транспортних та інших національних інтересів у геоекономічному просторі в рамках міжнародного права, двосторонніх та багатосторонніх договорів тощо, політико-дипломатичними, юридичними, зокрема й судовими та іншими несиловими методами й активна участь у міжнародних правових, торгівельних, фінансових та інших організаціях, залишається найбільш цивілізованим i перспективним у протистоянні агресору.

Досвід підтверджує, що тільки за умов мирного вирішення міжнародних спорів на усіх видимих i невидимих напрямах i “фронтах" можна досягти балансу національних інтересів, що сприяє налагодженню мирного співіснування протиборствуючих раніше сторін. I навпаки (див. рис.1).

Напрям другий - посилення боротьби та відстоювання національних інтересів $у$ інформаційному просторі з метою мобілізації прибічників, “демобілізаціі” противників та нейтралізації опонентів і тих хто намагається прямо чи опосередковано сприяти інформаційній агресії противника.

Напрям третій - посилення внутрішньої безпеки держави, основу якої має складати:

боротьба із втручаннями спецслужб агресора у внутрішні справи України;

протидія тероризму, бандитизму, сепаратизму;

боротьба зі шпіонажем та іноземними розвідками;

моніторинг та сприяння стабільності міжнаціональних, міжконфесійних, міжетнічних та інших національних стосунків тощо.

При цьому потрібно враховувати, що держава-агресор, окрім відвертої брехні, активно застосовує весь арсенал "асиметричних" засобів для дестабілізації внутріполітичної ситуації в Україні та на міжнародній арені.

Напрям четвертий - відбиття воснної агресії, відновлення та надійний захист територіальної цілісності держави. Гіркий досвід показує, що однією із основних умов вторгнення збройних угруповань російського агресора на територію України є підтримка їх певною частиною підготовленого заздалегідь спецслужбами РФ та його найманцями місцевого населення Криму i Донбасу. Відсутність такої підтримки унеможливила би окупацію чи анексію цих територій навіть 3 точки зору міжнародного права.

Важливим $\epsilon$ i своєчасне втручання у протиборство України з агресором та санкції проти Росії, що дозволило завадити розповзанню збройного конфлікту на інші території і спонукає у певній мірі агресора до завершення цього конфлікту на дипломатичному рівні. Ці дії варто посилювати. 


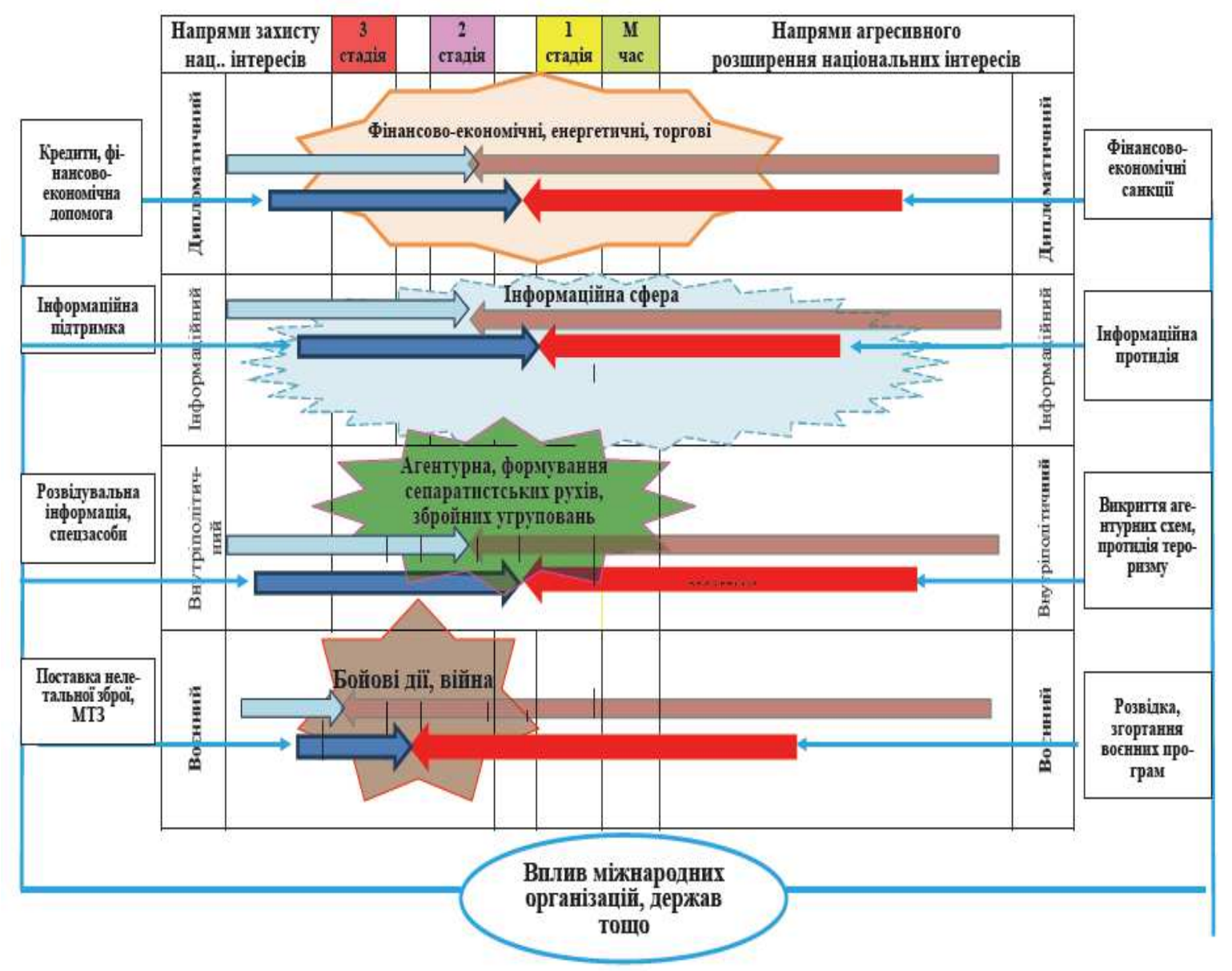

Рис.1. Основні напрями протистояння та протидії агресору

Деякі політики у якості основного шляху досягнення миру 3 агресором висувають тезу про ніби якусь потребу переговорів, зокрема, 3 російськими найманцями на Донбасі, що виявляється утопією, до якої підштовхує сам агресор. Тут варто згадати мудрі слова відомого німецького політика Отто фон Бісмарка, який радив не сподіватись на підписання єзуїтських угод з Росією, ніби нас виправдовуючих, бо вони не варті навіть того паперу, на якому написані. Яскравим підтвердженням цього $\epsilon$, підписаний Росією 5 грудня 1994 року, Будапештський меморандум про відмову України від ядерної зброї із зобов'язанням Росії “утримуватись від загрози силою чи іiі використання проти територіальної цілісності чи політичної незалежності України, і що ніяка іiі (РФ) зброя не буде використовуватися проти України". Бісмарк переконував, що 3 руськими варто або грати чесно, або взагалі не грати і ніколи не воювати бо на кожну воєнну хитрість вони дадуть відповідь непередбачуваною дурістю [11]. Це - урок, який знаходить своє відлуння і у Гаазькому суді.
В Україні зараз подекуди виголошуються заклики щодо введення на іï території чи на Донбасі “воєнного стану”. Представляється, що це відчайдушні, але теж не до кінця обдумані заклики. Тут треба зважити на те, що це непроста правова процедура, як за наслідками, так і за порядком іiї реалізації, якою навіть за бажанням чисельних лав прихильників цього заходу, не завжди може скористатися українська влада.

Законодавством України визначено два співзвучні але неоднозначні поняття: “стан війни" і "воєнний стан”. Відповідно до Гаазької конвенції про відкриття воєнних дій 1907 року та ст. 106 Конституції України оголошення стану війни здійснюється за поданням Президента України до Верховної Ради України у разі збройної агресії проти України. Він вносить таке подання та приймає рішення про використання Збройних Сил України.

Оголошення стану війни - це складна юридична та дипломатична процедура, яка полягає у офіційному повідомленні державиагресора в установленому міжнародними нормами порядку про припинення з нею миру та перехід до стану війни. Про оголошений 
стан війни необхідно одразу повідомити нейтральні держави.

Оголошення стану війни, навіть якщо воно не супроводжується власними воєнними діями, означає початок такого стану і має певні правові наслідки для обох сторін, зокрема:

припиняються дипломатичні i консульські зносини між державами, відкликається персонал посольств i консульств;

припиняється чинність укладених договорів (про ненапад, нейтралітет, про воєнний союз, економічні та культурні угоди між воюючими державами).

деякі багатосторонні договори також припиняють свою дію у відносинах між державами, які беруть участь у війні;

починають діяти міжнародні норми, прийняті спеціально для періоду збройного конфлікту (союзні договори та про взаємну і військову допомогу, договори стосовно правил ведення війни, причому останні не можуть бути денонсовані, тощо); майно, що є власністю ворожої держави (за винятком майна дипломатичних представництв і консульських установ), підлягає конфіскації;

торгові судна воюючих, що знаходилися до початку війни у ворожих портах, повинні залишити порт супротивника, для чого встановлюється певний термін для вільного їх виходу, після закінчення якого такі судна підлягають реквізиції i затриманню до закінчення війни незалежно від їхньої приналежності; військові кораблі підлягають обов' язковій реквізиції;

до громадян агресора може застосовуватися спеціальний режим: обмеження права на вибір місця проживання, інтернування або примусове поселення у визначені місця.

“Стан війнu” аж ніяк не можна плутати 3 "воєнним станом", тобто з особливим правовим режимом. Такий режим може бути введений в Україні або в окремих їі місцевостях лише в порядку, визначеному п.19 ст. 92 Конституції України та відповідним Законом України (див. рис. 2).

\section{ПОРЯДОК ВВЕДЕННЯ ВОЄННОГО СТАНУ}

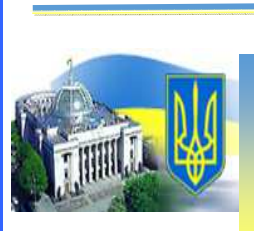

ВЕРХОВНАИ РАДА

1.ВИЗНАЧАЄТЬСЯ ВИКЛЮЧНО ЗАКОНОМ (п.19 ст.92 Конституції України)

2. У РАЗІ ОГОЛОШЕННЯ УКАЗУ, У 2-ДЕННИЙ СТРОК БЕЗ СКЛИКАННЯ СЕСІЇ ВРУ РОЗГЛЯДАС ПИТАННЯ ЩОДО ЗАТВЕРДЖЕННЯ УКАЗУ (ст. 5 ЗУ Про ПР в/стану)

3. ЗАТВЕРДЖУС УКАЗ ПРО ВВЕДЕННЯ ВОЄННОГО СТАНУ

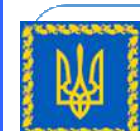

ПРЕЗИДЕНТ УКРАЇНИ

1. Видає Указ про введення воєн. стану в Україні або в окремих їі місщевостях

2. Негайно звертається до ВРУ щодо затвердження Указу

3. Подас одночасно до ВР проект закону про затвердження Указу

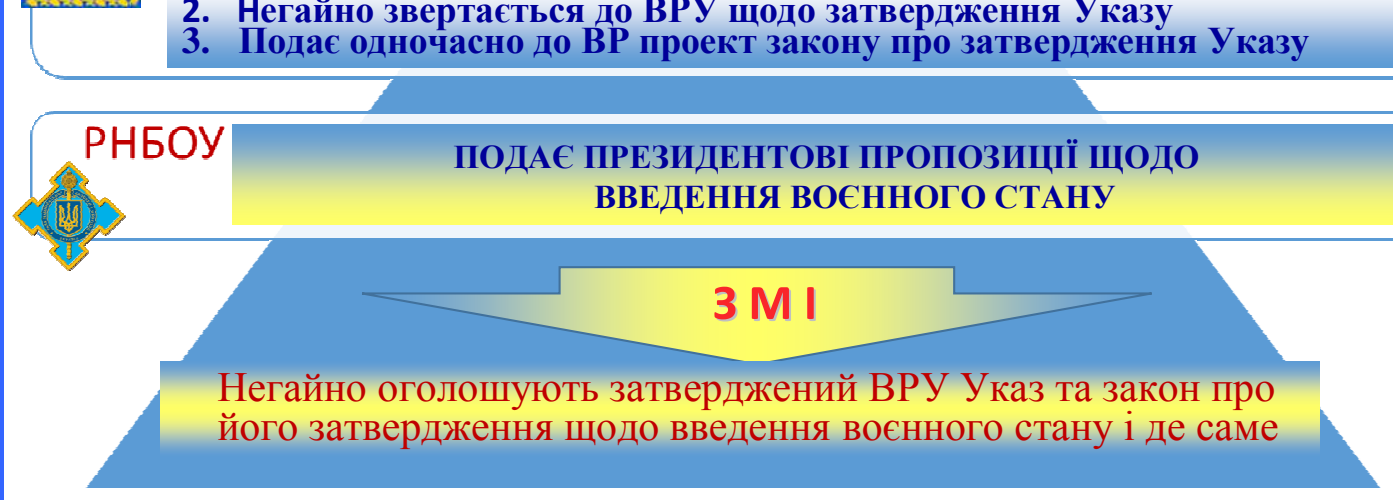

Рис. 2. Схема введення особливого правового режиму воснного стану

Особливий правовий режим воєнного стану може бути введений законом у разі:

а) збройної агресії чи загрози нападу;

б) небезпеки державній незалежності України, іiі територіальній цілісності.
Особливий правовий режим передбачає:

а) надання органам державної влади та місцевого самоврядування, військовому командуванню, військовим адміністраціям повноважень, необхідних для: 

агресії;

- відвернення загрози, відсічі збройної

- забезпечення національної безпеки;

- усунення загрози небезпеки незалежності України, іiі територіальній цілісності;

б) тимчасове, зумовлене загрозою, обмеження конституційних прав i свобод людини i громадянина та прав i законних інтересів юридичних осіб із зазначенням строку дії цих обмежень;

в) особливі заходи правового режиму:

- встановлення посиленої охорони важливих об' єктів держави;

- запровадження трудової повинності для працездатних осіб;

- використання потужностей та трудових ресурсів підприємств, установ i організацій усіх форм власності для потреб оборони;

- примусове відчужування майна, що перебуває у приватній або комунальній власності, вилучання майна державних підприємств;

- встановлення особливого режиму в'їзду i виїзду, обмеження свободи пересування громадян, іноземців та осіб без громадянства, а також рух транспортних засобів;

- встановлення військово-квартирної повинності для розквартирування військовослужбовців тощо.

Усього законом передбачено 24 таких особливі заходи щодо забезпечення правового режиму воєнного стану.

Окрім цього, в умовах особливого режиму воєнного стану забороняються:

1) зміна Конституції України та Конституції АР Крим;

2) проведення виборів Президента України та до Верховної Ради України, Верховної Ради АР Крим і органів місцевого самоврядування;

3) проведення всеукраїнських та місцевих референдумів; та акцій.

4) проведення страйків, масових зібрань

Відповідно до Міжнародного пакту про громадянські та політичні права у разі введення режиму воєнного стану необхідно негайно повідомити через Генерального секретаря $\mathrm{OOH}$ державам, які беруть участь у цьому пакті, про обмеження прав і свобод людини і громадянина, що є відхиленням від зобов'язань за Міжнародним пактом, та про межу цих відхилень i причини прийняття такого рішення із зазначенням дати припинення дії відповідних відхилень від зобов'язань, передбачених зазначеним пактом.

\section{Висновки.}

1. За наявних безпекових умов мирний захист i активна оборона України від російського агресора залишається найбільш актуальною стратегією сьогодення. Саме про такий формат оборонної стратегії йдеться у Воєнній доктрині України (п.21).

Протидія державі-агресору не може обмежуватись лише окремими військовими, економічними, інформаційними, внутрішньополітичними чи іншими заходами. Вагоме протистояння агресору може бути досягнуто лише за умови консолідованого застосування до нього рішучих та адекватних дій і заходів 3 боку усіх наявних сил і засобів та на усіх можливих напрямах i “фронтах" цієї нерівної боротьби за національні інтереси України.

2. Стрімкий розвиток засобів масової інформації має більш активно використовуватись для посилення інформаційного впливу як на світогляд населення держави-агресора та його приплічників, так і на світову спільноту на геополітичному просторі. Інформаційна сфера при цьому має стати одним із основних майданів протидії агресору.

3. Загострення боротьби агресора за розширення своїх інтересів та за лідерство на геополітичному просторі, намагання відновити втрачений вплив на міжнародній арені тощо, потребує суттєвих реформ і більш тісної консолідації міжнародних організацій, у першу чергу ООН та Ради безпеки, МВФ, ВТО, особливо в плані посилення відповідальності агресора за порушення ним чи навіть нехтування міжнародним правом і невиконання взятих на себе міжнародних зобов' язань, якими черговий раз знехтувала Росія.

4. Основним стратегічним напрямом протидії агресору за нинішніх умов залишається забезпечення готовності сектора безпеки і оборони України, іiі економіки та суспільства до відбиття російської агресії.

Напрямок подальших досліджень. Продовження досліджень сучасних підходів та процесів щодо протистояння агресору з метою розроблення більш ефективної стратегії протидіï російській агресії на усіх можливих напрямах і “фронтах”.

\section{СПИСОК ВИКОРИСТАНОЇ ЛІТЕРАТУРИ}

1. Резолюція XXIX сесії Генеральної Асамблеї ООН від 14.12.74. - № 3314. - Ст. ст. 1, 3.

2. Клімкін назвав кількість російського озброєння на Донбасі [Електронний ресурс]. - Режим 
доступу:https://ukr.lb.ua/news/2017/03/08/360646_ klimkin_nazvav_kilkist.html.

3. Заява Президента України за результатами зустрічі з Віце-Президентом США 16 січня 2017 року [Електронний ресурс]. - Режим доступу: http://www.president.gov.ua/ news/zayavaprezidenta-ukrayini-za-rezultatami-zustrichi-z-vicep-39490.

4. Радіо свобода. Новини / події. - 2017. - 15 березня [Електронний ресурс]. - Режим доступу: http://www.radiosvoboda.org/a/news/28371406.html

5. Порошенко розповів про політику безпеки, фінансування ЗСУ та перспективи професійної армії [Електронний ресурс]. - Режим доступу: http:// newsru.ua/ukraine/ 14oct2016/ politbezp.html.

6. Горбулін В. П. Війна і мир: п’ять сценаріїв для України//Стратегічна панорама. - 2015.- № 1. C. 5-11.
7. Руснак I. С. Підсумки та перспективи оборонного будівництва України в контексті реалізації воєнної політики держави // Стратегічні пріоритети. 2015. - № 4. - С. 35-44.

8. Руснак I. C. Національна безпека та підвищення обороноздатності України в контексті нових викликів і загроз / І.С. Руснак, В.В. Хижняк // Стратегічна панорама. - 2015. - № 1. - С. 12 -17.

9. НАТО і ЄС потрібна “велика стратегія”, щоб протистояти Путіну [Електронний ресурс]. Режим доступу: https://tsn.ua/svit/nato-i-yespotribna-velika-strategiya-schob-protistoyati-putinubritanskiy-general-890723.html.

10. Проблеми та пріоритети розвитку сектора безпеки і оборони// Defense. - 2015. - 6 червня.

11. Мудре слово. Афоризми Бісмарка про Росію та руських [Електронний ресурс]. - Режим доступу: http://www.aforizmik.ru/rossia-i-russkie/bismark-orossii-i-russkih.

Стаття надійшла до редакції 17.03.2017

Фролов В. С., к.воен.н., с.н.с.;

Саганюк Ф. В., к.юр.н., доцент;

Лобко М. Н., к.воен.н., доцент

Центр военно-стратегических исследований Национального университета обороны Украины имени Ивана Черняховского, Киев

\section{Некоторые подходы относительно стратегии противостояния и противодействия агрессору}

Резюме. Проанализированы научные и организационно-правовые подходы относительно формирования в секторе безопасности и обороны Украины стратегии мирного противостояния и противодействия агрессору.

Ключевые слова: агрессор, активная оборона, сектор безопасности и обороны Украины, силы обороны.

\section{Frolov, Ph.D; \\ F. Sahaniuk, Ph.D; \\ M. Lobko, Ph.D}

Center for Military and Strategic Studies National Defence University of Ukraine named after Ivan Chernyhovsky, Kyiv

Some approaches to the strategy of confrontation and counter the aggressor

Resume. Scientific organizational and legal approaches are analyzed in relation to forming in the sector of safety and defensive of Ukraine of strategy of peaceful opposition and counteraction to the aggressor.

Keywords. aggressor, active defense, security and defense sector of Ukraine, Defense Forces. 